\title{
Uterine Artery Pulsatility Index as a Pre- eclampsia Predictor in the 3 Trimesters in Women with Singleton Pregnancies
}

\section{Índice de pulsatilidade da artéria uterina como preditor de pré-eclâmpsia nos 3 trimestres em mulheres com gestações únicas}

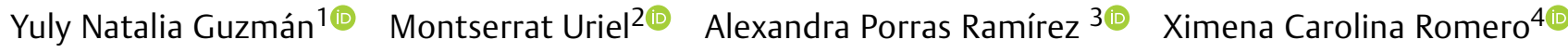 \\ ${ }^{1}$ Universidad El Bosque, El Bosque Research Group of Maternal Fetal \\ Medicine and Gynecology, Bogotá, Colombia \\ 2 Universidad El Bosque, El Bosque Research Group of Maternal Fetal \\ Medicine and Gynecology, Ecodiagnóstico El Bosque SAS, Los Cobos \\ Address for correspondence Professor Ximena Romero Infante, MD. \\ EspMFM, Av. Carrera 9 \# 131a-02. Ecodiagnóstico El Bosque S. A. S, \\ Calle 134 \# 7B - 83. Bogotá, Colombia \\ (e-mail: romeroximena@unbosque.edu.co).
} Medical Center, Bogotá, Colombia

3 Universidad El Bosque, Research Group Community Medicine and Collective Health, Los Cobos Medical Center, Bogotá, Colombia

${ }^{4}$ Universidad El Bosque, El Bosque Research Group of Maternal Fetal Medicine and Gynecology, Ecodiagnóstico El Bosque SAS, Los Cobos Medical Center, Bogotá, Colombia

Rev Bras Ginecol Obstet 2021;43(12):904-910.

\begin{abstract}
Objective To evaluate the mean uterine artery pulsatility index (UtAPI) in each trimester of pregnancy as a predictor of early or late pre-eclampsia (PE) in Colombian pregnant women.

Methods The UtAPI was measured in singleton pregnancies in each trimester. Uterine artery pulsatility index as predictor of PE was evaluated by odds ratio (OR), receiver operating characteristic (ROC) curves, and Kaplan-Meier diagram.

Results Analysis in the $1^{\text {st }}$ and $3^{\text {rd }}$ trimester showed that abnormal UtAPI was associated with early PE (OR: 5.99: 95\% confidence interval [Cl]: 1.64-21.13; and OR: $10.32 ; 95 \% \mathrm{Cl}: 2.75-42.49$, respectively). Sensitivity and specificity were 71.4 and

Keywords

- uterine artery doppler

- preeclampsia; pregnancy

- perinatal care

- screening 79.6\%, respectively, for developing PE (area under the curve [AUC]: 0.922). The KaplanMeier curve showed that a UtAPI of $0.76(95 \% \mathrm{Cl}: 0.58-1.0)$ in the $1^{\text {st }}$ trimester was associated with early PE, and a UtAPI of $0.73(95 \% \mathrm{Cl}: 0.55-0.97)$ in the $3^{\text {rd }}$ trimester was associated with late PE.

Conclusion Uterine arteries proved to be a useful predictor tool in the $1^{\text {st }}$ and $3^{\text {rd }}$ trimesters for early PE and in the $3^{\text {rd }}$ trimester for late PE in a pregnant population with high prevalence of $\mathrm{PE}$.
\end{abstract}

received

November 28, 2020

accepted after revision

October 13, 2021
DOI https://doi.org/

$10.1055 / \mathrm{s}-0041-1740273$. ISSN $0100-7203$. (c) 2021. Federação Brasileira de Ginecologia e Obstetrícia. All rights reserved.

This is an open access article published by Thieme under the terms of the Creative Commons Attribution License, permitting unrestricted use, distribution, and reproduction so long as the original work is properly cited. (https://creativecommons.org/licenses/by/4.0/)

Thieme Revinter Publicações Ltda., Rua do Matoso 170, Rio de Janeiro, RJ, CEP 20270-135, Brazil 


\section{Resumo}

\section{Palavras-chave \\ - doppler da artéria uterina \\ - pré-eclâmpsia; gravidez \\ - cuidado perinatal \\ - triagem}

Objetivo Avaliar o índice médio de pulsatilidade da artéria uterina (UtAPI) em cada trimestre da gravidez como preditor de pré-eclâmpsia (PE) precoce ou tardia em gestantes colombianas.

Métodos O UtAPI foi medido em gestações únicas em cada trimestre. O UtAPI como preditor de PE foi avaliado por odds ratio (OR), curvas receiver operating characteristic (ROC) e diagrama de Kaplan-Meier.

Resultados A análise no $1^{\circ}$ e $3^{\circ}$ trimestres mostrou que um UtAPI anormal foi associado com PE inicial (OR: 5,99; intervalo de confiança [IC] 95\%: 1,64-21,13; OR: 10,32; IC95\%: 2,75-42,49, respectivamente). A sensibilidade e a especificidade foram de 71,4 e $79,6 \%$, respectivamente, para o desenvolvimento de PE (area under the curve [AUC]: 0,922). A curva de Kaplan-Meier mostrou que um UtAPI de 0,76 (IC95\%: 0,58$1,0)$ no $1^{\circ}$ trimestre foi associado com PE precoce, e que um UtAPI de 0,73 (IC95\%: $0,55-0,97)$ no $3^{\circ}$ trimestre foi associado com PE tardia.

Conclusão As artérias uterinas mostraram ser uma ferramenta preditora útil no $1^{\circ} \mathrm{e}$ $3^{\circ}$ trimestres para $\mathrm{PE}$ inicial e no $3^{\circ}$ trimestre para $\mathrm{PE}$ tardia em uma população de gestantes com alta prevalência de PE.

\section{Introduction}

Pre-eclampsia (PE) is a disease with a high percentage of maternal and perinatal complications and continues to be one of the main causes of maternal death worldwide. ${ }^{1-4}$ Several methods have been studied to classify low- and high-risk populations; in recent years, early screening has been increasingly performed in an attempt to reduce PE prevalence through specific pharmacological interventions. ${ }^{4-6}$

Several research groups, such as the National Institute for Health and Care Excellence (NICE), the American College of Obstetricians and Gynecologists (ACOG), and the Fetal Medicine Foundation (FMF), have analyzed screening methods for $P E$ in which different parameters regarding maternal history, clinical symptoms, laboratory results, and biophysical variables are evaluated. One of the biophysical measures is the mean uterine artery pulsatility index (UtAPI). ${ }^{7,8}$

The pathophysiology of PE has been explained by several theories. The most accepted etiology in recent years is that PE is a pathology secondary to an altered placental development, manifested by the increase in the flow resistance of the uterine arteries. ${ }^{1,8-11}$ These alterations have been observed in the $1^{\text {st }}, 2^{\text {nd }}$, and $3^{\text {rd }}$ trimesters of the pregnancies that develop PE. ${ }^{12,13}$ Furthermore, uterine arteries were compared using Doppler in each trimester for predicting late PE; as a result, late PE can be best predicted during the $3^{\text {rd }}$ trimester. ${ }^{13,14}$ A systematic review has described that the $2^{\text {nd }}$ trimester is the best time to predict overall PE. ${ }^{15}$ Moreover, relevant international studies have evaluated the distribution of UtAPI in different populations during the course of pregnancy. ${ }^{1,7,16-18}$ In Latin America, there are no comparable studies that provide information about these values throughout the pregnancy or their association with PE.

Pre-eclampsia is classified as early and late, being differentiated by gestational age at onset. In early PE cases, the presentation is before 34 gestational weeks (GWs). ${ }^{10,19}$ This period is frequently associated with various unfortunate events, such as severe PE, eclampsia, hemolysis, elevated liver enzymes, and low platelet count (HELLP) syndrome, maternal death, admission to obstetric intensive care unit (ICU), admission to neonatal ICU, low birthweight, and perinatal death. $^{3}$

According to information dated from 2014, hypertensive disorders are the second leading cause of death in pregnant women in the Latin American and Caribbean population.,20 In Bogotá, Colombia, PE is the leading cause of maternal death, according to the Department of National Statistics Data Bases of 2017. ${ }^{21}$ Thus, early screening for hypertensive disorder is crucial to optimize or develop clinical strategies and public interest to reduce PE cases. Unfortunately, in the Colombian population, no information about specific characteristics of uterine artery Doppler study during the three trimesters of pregnancy is available.

The present study aimed mainly to evaluate the mean UtAPI measured in each trimester of pregnancy as a predictor of early or late PE in a sample of Colombian pregnant women.

\section{Methods}

The data for the present study were derived from a database of 566 pregnant women $>14$ years old with singleton pregnancies assessed 2 two hospitals in the city of Bogotá, Colombia, from a prospective study in which predictive tests of PE were analyzed in Colombian pregnant women in the period between October 2014 and March 2018. For the present work, pregnancies with major fetal malformations, chromosomopathies, and those under threat of miscarriage were excluded. During the $1^{\text {st }}$ visit, between $11+0$ and $13+6$ GWs, a clinical history regarding the sociodemographic and clinical characteristics of the patients was obtained. Doppler study of the uterine arteries was performed in the $1^{\text {st }}$ trimester between $11+0$ and $13+6$ GWs, 
in the $2^{\text {nd }}$ trimester between $18+0$ and $24+0 \mathrm{GWs}$, and in the $3^{\text {rd }}$ trimester between $28+0$ to $34+0$ GWs. Gestational age was determined by measuring the fetal crown-rump length from $11+0$ GWs to $13+0$ GWs.

Regarding the characteristics of the patients, the following demographic variables are included: maternal age, ethnic origin, and socioeconomic level (classified as high, middle, and low). The following clinical variables were also considered: medical history of chronic hypertension, pregestational diabetes, obesity defined as body mass index (BMI) $\geq 30 \mathrm{Kg} / \mathrm{m} 2$, systemic lupus erythematosus, antiphospholipid antibody syndrome, personal and family history of PE, parity (nulliparity versus non-nulliparity), smoking habit during pregnancy, maternal BMI, gestational age at the time of PE diagnosis, and gestational age at the end of pregnancy.

Doppler ultrasound examinations were performed transabdominally. Uterine artery pulsatility index measuring techniques were used according to the guidelines by Khalil et al. ${ }^{22}$. At $11+0$ to $13+6 \mathrm{GWs}$, a midsagittal section of the uterus was obtained, and the cervical canal and internal cervical os were identified. Subsequently, the transducer was gently tilted from side to side, and color flow mapping was used to identify each uterine artery measurements were taken before the uterine artery branches into the arcuate arteries. $^{22-24}$

At $18+0$ to $24+6$ GWs and at $28+0$ to $34+0$ GWs, the transducer was placed longitudinally in the iliac fossa, parallel to the iliac crest and to the uterine wall. Then, color Doppler was used to identify each uterine artery at the apparent crossover with the external iliac arteries. After the identification of each uterine artery, pulsed-wave Doppler was used, with the sampling gate set at between 2 and $3 \mathrm{~mm}$ to cover the whole vessel. Care was taken to ensure that the angle of insonation was $<30^{\circ}$ and that the peak systolic velocity was $>60 \mathrm{~cm} / \mathrm{s}$, so that the uterine artery, rather than the arcuate artery, was examined. When three similar waveforms were obtained consecutively, the pulsatility index was measured and the mean UtAPI of the left and right arteries was calculated. $^{22,23}$ The presence or absence of a diastolic notch was not considered in the present study. The mean UtAPI was analyzed qualitatively according to the normality and abnormality criteria described by Gómez et al. ${ }^{17}$ in their study, which was developed in a Spanish population, using the $95^{\text {th }}$ percentile; hence, UtAPI values above this range were considered abnormal. All Doppler studies were performed by sonographers who had received the Certificate of Competence in Doppler of the FMF.

Patients were diagnosed with PE according to the 2013 diagnostic criteria of hypertension in pregnancy. ${ }^{25-28}$ In addition, the gestational age at the onset of PE was considered; PE was classified as early PE when it starts before 34 GWs and as late PE when it starts after this gestational age. $^{10,19}$

Informed consent was obtained from all patients. The present study was approved by the ethical committees of each participating hospital. In addition, the ethical principles for human research from the Helsinki Declaration and the
Colombian resolution 8430 of 1993 were considered in the present study, and it was classified as an investigation with minimum risk. ${ }^{29}$

Absolute and relative frequencies were performed with their respective confidence intervals (CIs) to describe the characteristics of the patients. Comparisons of groups were analyzed by the student t-test, the Mann-Whitney U test, and the Fisher test, considering $p<0.05$ to stablish statistical differences. To find the possible associations between uterine pulsatility in each trimester and the development of PE, the odds ratio (OR) was calculated. Receiver operating characteristic (ROC) curves and the area under the curve (AUC) were made to calculate the sensitivity and specificity of UtAPI in order to determine the risk of developing PE. Kaplan-Meier probability diagrams were calculated to evaluate the probability of developing PE (early and late) related with gestational age in the upper and lower quintile of the UtAPI.

\section{Results}

The present study included 527 pregnant women who met the inclusion criteria, out of a total of 566 women who were studied. The average age was 27.4 years old, and $97.3 \%$ of the participants were of mixed race. Furthermore, $96.9 \%$ of these women were from middle and low socioeconomic levels. Sociodemographic characteristics and pathological history of the study population are summarized in - Table $\mathbf{1}$, as well as the comparation between groups.

In the present study, 42 women (7.9\%) had PE, of whom 34 (6.4\%) had late PE and 8 (1.5\%) had early PE. The average gestational age at the moment of diagnosis of early and late PE was $30+1 \mathrm{GWs}(21+0$ to $33+0 \mathrm{GWs})$ and $37+1 \mathrm{GWs}$ $(34+0$ to $40+4 \mathrm{GWs})$, respectively. In the $1^{\text {st }}$ trimester, $12.9 \%$ (68) of the pregnant women had an UtAPI $>95^{\text {th }}$ percentile. The mayor ratio of patients with UtAPI $>95^{\text {th }}$ percentile in the 1 st trimester was obtained in the group of patients who developed early PE, 5 patients of the 8 (62.5\%). In the $2^{\text {nd }}$ trimester, 14 women did not attend the ultrasound appointment, but, of the new total of patients who attended to the $2^{\text {nd }}$ appointment, 9.6\% (51) had abnormal UtAPI. Besides, the group that developed early PE showed the highest ratio of patients with UtAPI $>95^{\text {th }}$ percentile ( 5 patients of the 8 who developed early PE). Finally, in the $3^{\text {rd }}$ trimester, 20 women were lost to follow-up. Of the patients evaluated in the $3^{\text {rd }}$ trimester, $12.7 \%$ (67) of women who were in the $3^{\text {rd }}$ trimester of gestation had a UtAPI $>95$ th percentile; the highest percentage of patients with UtAPI $>95^{\text {th }}$ percentile was in the group of early PE (75\%) ( 6 patients of the 8 that developed early PE). The analysis of the ORs showed a positive association between abnormal UtAPI in the $1^{\text {st }}$ trimester and the development of early PE (OR: 5.9; 95\%CI: 1.64-1.13), with statistically significant differences. An association between having UtAPI $>95^{\text {th }}$ percentile in the $3^{\text {rd }}$ trimester and early PE (OR: 10.32; 95\%Cl: 2.75-42.49) was found, as shown in - Table 2.

Receiver operating characteristic curves were made to evaluate the ability to discriminate the likelihood of 
Table 1 Sociodemographic and clinical characteristics

\begin{tabular}{|c|c|c|c|c|c|}
\hline $\begin{array}{l}\text { Sociodemographic characteristics/ } \\
\text { pathological history }\end{array}$ & $\begin{array}{l}\text { Pregnant women } \\
\text { included }(n=527)\end{array}$ & $\begin{array}{l}\text { Without PE } \\
(n=485)\end{array}$ & Early PE $(n=8)$ & Late PE $(n=34)$ & p-value \\
\hline Median age, years old median (IQR) & $27.0(14-44)$ & $27.8(14-44)$ & $27.9(17-38)$ & $30.4(15-42)$ & $0.062^{*}$ \\
\hline $\mathrm{BMI}$ in $\mathrm{Kg} / \mathrm{m}^{2}(\mathrm{IQR})$ & $24.6(16.7-40.5)$ & $26.6(17.9-400)$ & $29.0(18.5-39.8)$ & $28.3(19.3-35.5)$ & $0.429^{* *}$ \\
\hline $\begin{array}{l}\text { Gestational age at delivery } \\
\text { in weeks (IQR) }\end{array}$ & $39.0(28.2-43.1)$ & $37.5(29.3-43.1)$ & $35.5(30.4-40.4)$ & $37.5(36-40.4)$ & $0.721^{* *}$ \\
\hline Obesity \% & $47(8.9)$ & $39(8.0)$ & $2(25.0)$ & $6(17.6)$ & $0.043^{* * *}$ \\
\hline Pregestational diabetes \% & $3(0.56)$ & $2(0.4)$ & $1(12.5)$ & 0 & - \\
\hline $\mathrm{CH} \%$ & $14(2.6)$ & $6(1.2)$ & $5(62.5)$ & $3(8.8)$ & $0.399^{* * *}$ \\
\hline SLE \% & $2(0.38)$ & $1(0.2)$ & 0 & $1(2.9)$ & - \\
\hline APS \% & $1(0.19)$ & 0 & $1(12.5)$ & 0 & - \\
\hline Smoking habit \% & $47(8.9)$ & $40(8.2)$ & $3(37.5)$ & $4(11.7)$ & $0.04^{* * *}$ \\
\hline Nulliparity \% & $203(38.5)$ & $191(39.3)$ & $3(37.5)$ & $9(26.4)$ & $0.002^{* * *}$ \\
\hline
\end{tabular}

Abbreviation: APS, antiphospholipid antibody syndrome; BMI, body mass index; $\mathrm{CH}$, chronic hypertension; IQR, interquartile range; PE, preeclampsia; SLE, systemic lupus erythematosus.

*Mann-Whitney U test; **Student's t-test; ${ }^{* * *}$ Fisher test.

Table 2 Bivariate analysis (OR) of abnormal UtAPI and developing or not $\mathrm{PE}$

\begin{tabular}{llll}
\hline & Without PE & Early PE & Late PE \\
\hline $\begin{array}{l}\text { UtAPI }>95^{\text {th }} \\
\text { percentile } \\
\text { by trimester }\end{array}$ & OR (95\%Cl) & OR (95\%Cl) & OR (95\%Cl) \\
First & $1.01(0.98-1.23)$ & $5.99(1.64-21.13)^{*}$ & $0.46(0.07-1.73)$ \\
Second & $0.98(0.75-2.36)$ & $4.74(0.94-19.66)$ & $1.98(0.64-5.21)$ \\
Third & $1.10(0.45-1.87)$ & $10.32(2.75-42.49)^{*}$ & $1.65(0.59-4.05)$ \\
\hline
\end{tabular}

Abbreviations: $\mathrm{Cl}$, confidence interval; OR, odds ratio; PE, pre-eclampsia; UtAPI, uterine artery pulsatility index.

${ }^{*}$ Statistically significant between groups.

developing PE. The ROC shows the importance of the UtAPI in the $1^{\text {st }}$ and the $2^{\text {nd }}$ trimester, so that the model achieves a prediction of $92.2 \%$ of the risk of developing $\mathrm{PE}$, with a sensitivity and a specificity of 71.4 and $79.6 \%$, respectively, by using all the characteristics described in -Figure 1. At the 1 st and 2nd trimesters, the sensitivity of the UtAPI was $20 \%$ of each one.

The analysis of the Kaplan-Meier probability diagram demonstrated the relationship between the upper quintile of the UtAPI 0.76 (95\% CI: $0.58-1.0)$ in the $1^{\text {st }}$ trimester and the development of early $\mathrm{PE}$, with statistically significant results. The risk of late PE for the upper quintile of UtAPI 0.73 (95\%CI: $0.55-0.97)$ in the $3^{\text {rd }}$ trimester was statistically significant. The Kaplan-Meier cumulative risk of PE is shown in -Figure 2.

\section{Discussion}

According to the findings of the present, PE was found in $7.9 \%$ of the participants, suggesting that the Colombian popula- tion has a higher incidence of PE than the world population (between 5 and 7\%), with a high percentage of maternal and perinatal complications. ${ }^{30-32}$ Additionally, in relation to PE onset, 34 (6.4\%) pregnant women had late PE and 8 (1.5\%) had early PE onset.

Considering the elevated incidence of this hypertensive disease, it is important to have knowledge about its probable etiology. The increase in the flow resistance of the uterine arteries is one of the bases of the pathophysiology of PE, as referenced by O'Gorman et al. ${ }^{12}$ These alterations could be shown by Doppler changes in uterine arteries in each trimester or in all trimesters; consequently these variations have been observed in the $1^{\text {st }}$, the $2^{\text {nd }}, 33$ and the $3^{\text {rd }}$ trimesters. $^{11,33}$ Other researches, as Mula et al., ${ }^{13}$ have examined Doppler changes of the uterine artery in all trimesters, as our study, in which women were evaluated by trimester attending their routine care. In the present study, abnormal UtAPI was found in all 3 trimesters of pregnancy in $16.6 \%$ of the pregnant women with PE.

In this context, Doppler changes found in uterine arteries by trimester are consistent with other research. In 2016, Arrue et al. $^{34}$ concluded that patients with an abnormal UtAPI in the $3^{\text {rd }}$ trimester had a higher rate of PE and adverse perinatal outcomes independent of UtAPI values in the $1^{\text {st }}$ and $2^{\text {nd }}$ trimesters of pregnancy. In 2013, Jamal et al. ${ }^{33}$ found that an elevated UtAPI in the $2^{\text {nd }}$ and $3^{\text {rd }}$ trimesters of pregnancy was associated with a higher risk of adverse pregnancy outcomes, such as PE, intrauterine growth restriction (IUGR), intrauterine fetal death, and preterm delivery, than in the $1^{\text {st }}$ trimester. Notably, in the present study, abnormal UtAPI in the $1^{\text {st }}$ and $3^{\text {rd }}$ trimesters was associated with early PE, with a statistically significant difference. The early PE association in the $3^{\text {rd }}$ trimester was higher than in the $1^{\text {st }}$ trimester, conforming to the abovementioned studies in which an abnormal UtAPI in the $3^{\text {rd }}$ trimester had a greater risk of developing adverse outcomes, such as PE. 


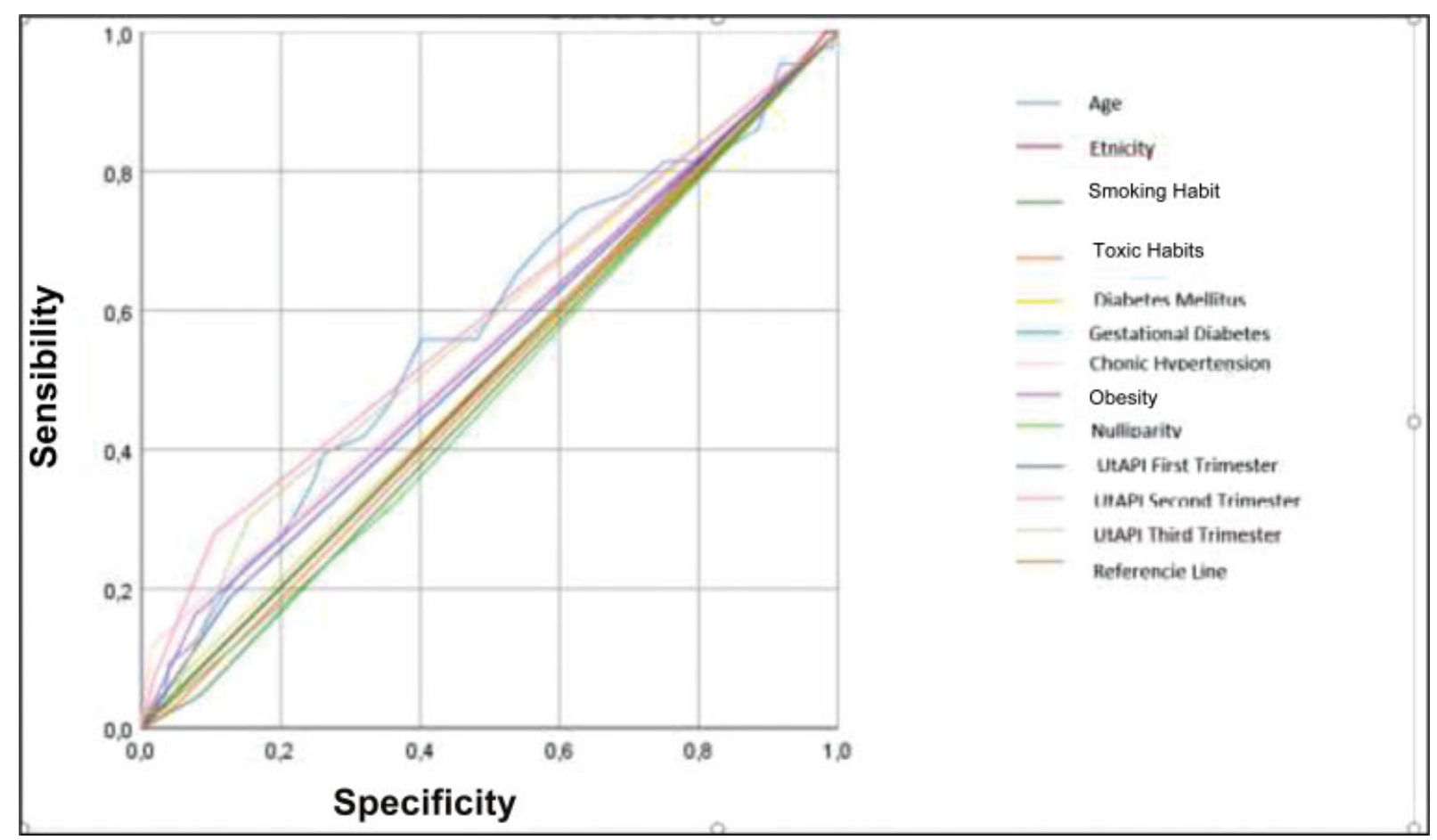

Fig. 1 Receiver operating characteristic curve.

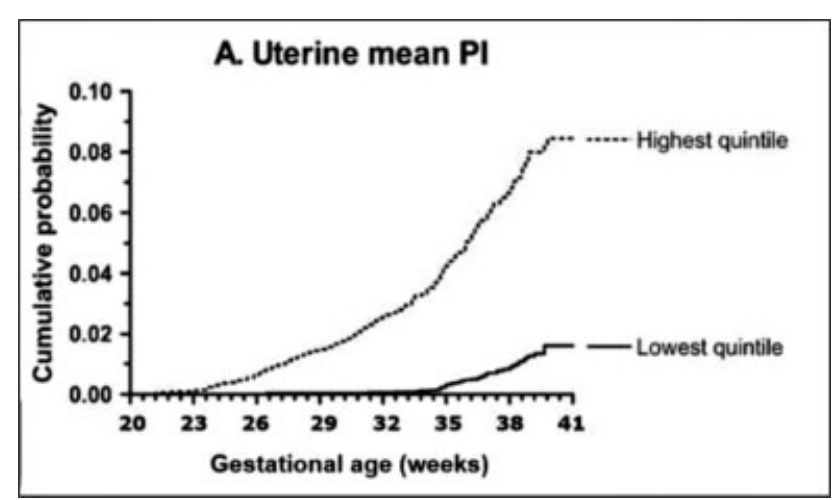

Fig. 2 Kaplan-Meier probability diagram of early and late preeclampsia and their relationship with gestational age and the upper and lower quintiles of uterine artery pulsatility index.

Likewise, regarding the $2^{\text {nd }}$ trimester, a systematic review and meta-analysis by Cnossen et al. ${ }^{15}$ has found a higher prediction of PE and IUGR when UtAPI was $>95^{\text {th }}$ percentile alone or combined with notching in the $2^{\text {nd }}$ trimester when compared with abnormal UtAPI in $1^{\text {st }}$ and $3^{\text {rd }}$ trimesters. In 2013, 2,410 pregnant women were evaluated to determine the biological interaction between uterine artery Doppler and blood pressure in the $2^{\text {nd }}$ trimester for the development of early and late PE. ${ }^{35}$ In this study, Takahashi et al. ${ }^{35}$ found a cumulative risk of early PE in women with both abnormal UtAPI and elevated blood pressure, which is in contrast with the present study, in which the association was not statistically significant in the $2^{\text {nd }}$ trimester.

Additionally, in 2019, Mula et al. ${ }^{13}$ evaluated the prediction of late PE by measuring the UtAPI in each trimester; they found that UtAPI measurement in the $3^{\text {rd }}$ trimester was more sensitive (78\%) and specific (82\%) than in the 2 other trimesters (AUC: 0.86). In the present study, according to ROC curves (AUC: 0.922 ), the sensitivity and specificity to determine the risk of developing PE were 71.4 and $79.6 \%$, respectively.

Focusing on PE predictor tools, similarly, screening methods for PE with evaluation of different parameters, such as maternal history, clinical, laboratories, and biophysical variables (such as UtAPI, evaluated in the present study), were analyzed. Andrietti et al., ${ }^{14}$ who demonstrated that the combined measurement of UtAPI, mean arterial pressure (MAP), and serum placental growth factor in the $1^{\text {st }}$ and/or $2^{\text {nd }}$ trimesters did not improve the prediction of early PE compared with screening in the $3^{\text {rd }}$ trimester. In the present study, more cases of late PE were identified by UtAPI measurements in the $3^{\text {rd }}$ trimester. ${ }^{14}$ In general, among the biophysical measures, UtAPI has become one of the most useful parameters for PE screening since it is more available than measurements of placental proteins, which are not accessible for the entire population as part of their health insurance plan, as it happens in Colombia.

Consequently, UtAPI measurement has been evaluated with inconsistent results between researches, with the present study being one of the few that analyzed the prognostic ability in each trimester of pregnancy in the same group of women, and these results show in which trimester the measurement of uterine arteries was more efficient to improve the PE screening rate in a country with a high incidence of PE. The main limitations of the present study were that we incurred a random error because of the small sample size. Furthermore, a selection bias was observed, given that the patients included in the present study corresponded to a specific population of Bogotá. 


\section{Conclusion}

In conclusion, the measurement of the UtAPI in the $1^{\text {st }}$ and $3^{\text {rd }}$ trimesters of pregnancy may be a useful technique for the screening of early PE and, in $3^{\text {rd }}$ trimester, for late PE. However, in the present study, the result of this predictor tool was limited by the sample size. Hence, further studies are necessary to validate the predictive and prognostic ability of UtAPI in each trimester regarding PE in the Colombian population in isolation and in combination with other PE predictors.

\section{Contributors}

All the authors contributed with the project and data interpretation, the writing of the article, the critical review of the intellectual content, and with the final approval of the version to be published.

\section{Conflict of Interests}

The authors have no conflict of interests to declare.

\section{Acknowledgments}

The authors would like to thank the following institutions: Ecodiagnóstico El Bosque Unit Centre, Clinica El Bosque, South West Health Services Unit - Hospital Occidente de Kennedy, and Universidad El Bosque for their contribution in the present study.

\section{References}

1 Tayyar A, Guerra L, Wright A, Wright D, Nicolaides KH. Uterine artery pulsatility index in the three trimesters of pregnancy: effects of maternal characteristics and medical history. Ultrasound Obstet Gynecol. 2015;45(06):689-697. Doi: 10.1002/ uog.14789

2 Say L, Chou D, Gemmill A, Tunçalp Ö, Moller A-B, Daniels J, et al. Global causes of maternal death: a WHO systematic analysis. Lancet Glob Health. 2014;2(06):e323-e333. Doi: 10.1016/S2214109X(14)70227-X

3 Guzmán-Yara YN, Parra-Amaya E, Javela-Rugeles JD, BarriosTorres JC, Montalvo-Arce C, Perdomo-Sandoval HL. Expectant management in non-severe pre-eclampsia obstetric and perinatal outcomes in a high complexity hospital in Neiva (Colombia). Rev Colomb Obstet Ginecol. 2018;69(03):160-168. Doi: 10.18597/ rcog.3075

4 Wright D, Akolekar R, Syngelaki A, Poon LC, Nicolaides KH. A competing risks model in early screening for preeclampsia. Fetal Diagn Ther. 2012;32(03):171-178. Doi: 10.1159/000338470

5 Rolnik DL, Wright D, Poon LCY, Syngelaki A, O'Gorman N, de Paco Matallana C, et al. ASPRE trial: performance of screening for preterm pre-eclampsia. Ultrasound Obstet Gynecol. 2017;50 (04):492-495. Doi: 10.1002/uog.18816

6 Yücel B, Gedikbasi A, Dündar O, Olgac Y, Yıld $\iota r \iota m$ D, Y $\iota l d \iota r \iota m$ G, et al. The utility of first trimester uterine artery Doppler, placental volume and PAPP-A levels alone and in combination to predict preeclampsia. Pregnancy Hypertens. 2016;6(04):269-273. Doi: 10.1016/j.preghy.2016.04.007

7 O'Gorman N, Wright D, Poon LC, Rolnik DL, Syngelaki A, de Alvarado $\mathrm{M}$, et al. Multicenter screening for pre-eclampsia by maternal factors and biomarkers at 11-13 weeks' gestation: comparison with NICE guidelines and ACOG recommendations. Ultrasound Obstet Gynecol. 2017;49(06):756-760. Doi: 10.1002/ uog. 17455
8 Gestational hypertension and preeclampsia. ACOG Practice Bulletin No. 222. Obstet Gynecol. 2020;135(06):e237-e260. Doi: 10.1097/AOG.0000000000003891

9 Mazhar K, Bhatti F, Maraj H. Pre-eclampsia. InnovAiT.. 2014;7 (01):14-24. Doi: 10.1177/1755738013499318

10 Orabona R, Donzelli CM, Falchetti M, Santoro A, Valcamonico A, Frusca T. Placental histological patterns and uterine artery Doppler velocimetry in pregnancies complicated by early or late preeclampsia. Ultrasound Obstet Gynecol. 2016;47(05):580-585. Doi: 10.1002/uog.15799

11 Valiño N, Giunta G, Gallo DM, Akolekar R, Nicolaides KH. Uterine artery pulsatility index at 30-34 weeks' gestation in the prediction of adverse perinatal outcome. Ultrasound Obstet Gynecol. 2016;47(03):308-315. Doi: 10.1002/uog.14898

12 O'Gorman N, Tampakoudis G, Wright A, Wright D, Nicolaides KH. Uterine artery pulsatility index at $12,22,32$ and 36 weeks' gestation in screening for pre-eclampsia. Ultrasound Obstet Gynecol. 2016;47(05):565-572. Doi: 10.1002/uog.15819

13 Mula R, Meler E, Albaiges G, Rodriguez I. Strategies for the prediction of late preeclampsia. J Matern Fetal Neonatal Med. 2019;32(22):3729-3733. Doi: 10.1080/14767058.2018.1471592

14 Andrietti S, Carlucci S, Wright A, Wright D, Nicolaides KH. Repeat measurements of uterine artery pulsatility index, mean arterial pressure and serum placental growth factor at 12, 22 and 32 weeks in prediction of pre-eclampsia. Ultrasound Obstet Gynecol. 2017;50(02):221-227. Doi: 10.1002/uog.17403

15 Cnossen JS, Morris RK, ter Riet G, Mol BWJ, van der Post JAM, Coomarasamy A, et al. Use of uterine artery Doppler ultrasonography to predict pre-eclampsia and intrauterine growth restriction: a systematic review and bivariable meta-analysis. CMAJ. 2008;178(06):701-711. Doi: 10.1503/cmaj.070430

16 Poon LC, Karagiannis G, Leal A, Romero XC, Nicolaides KH. Hypertensive disorders in pregnancy: screening by uterine artery Doppler imaging and blood pressure at 11-13 weeks. Ultrasound Obstet Gynecol. 2009;34(05):497-502. Doi: 10.1002/uog.7439

17 Gómez O, Figueras F, Fernández S, Bennasar M, Martínez JM, Puerto B, et al. Reference ranges for uterine artery mean pulsatility index at 11-41 weeks of gestation. Ultrasound Obstet Gynecol. 2008;32(02):128-132. Doi: 10.1002/uog.5315

18 Shwarzman P, Waintraub AY, Frieger M, Bashiri A, Mazor M, Hershkovitz R. Third-trimester abnormal uterine artery Doppler findings are associated with adverse pregnancy outcomes. J Ultrasound Med. 2013;32(12):2107-2113. Doi: 10.7863/ultra.32.12.2107

19 Sibai BM. Management of late preterm and early-term pregnancies complicated by mild gestational hypertension/pre-eclampsia. Semin Perinatol. 2011;35(05):292-296. Doi: 10.1053/j. semperi.2011.05.010

20 Romero XC, Gutiérrez AM, Rojas NA, Ramírez A, Aldana J, Eslava $\mathrm{M}$, et al. Incidencia de los trastornos hipertensivos en el embarazo, y características clínico-demográficas en tres instituciones en Bogotá, D.C., Colombia. Investig Segur Soc Salud.. 2018;20(02): 21-30

21 Organización Panamericana de la Salud. Indicadores de salud: aspectos conceptuales y operativos [Internet]. Washington (DC): OPS; 2018 [cited 2020 Jul 12]. Available from: https://www. ministeriodesalud.go.cr/index.php/vigilancia-de-la-salud/indicadores-de-salud-boletines/4072-indicadores-de-salud-aspectos-conceptuales-y-operativos-2018/file

22 Khalil A, Nicolaides KH. How to record uterine artery Doppler in the first trimester. Ultrasound Obstet Gynecol. 2013;42(04): 478-479. Doi: 10.1002/uog.12366

23 Bhide A, Acharya G, Bilardo CM, Brezinka C Cafici D, HernandezAndrade E, et al. ISUOG practice guidelines: use of Doppler ultrasonography in obstetrics. Ultrasound Obstet Gynecol. 2013;41(02):233-239. Doi: 10.1002/uog.12371

24 Plasencia W, Maiz N, Poon L, Yu C, Nicolaides KH. Uterine artery Doppler at $11+0$ to $13+6$ weeks and $21+0$ to $24+6$ weeks in 
the prediction of pre-eclampsia. Ultrasound Obstet Gynecol. 2008;32(02):138-146. Doi: 10.1002/uog.5402

25 Bibbins-Domingo K, Grossman DC, Curry SJ, Curry SJ, Barry MJ, Davidson KW, et al; US Preventive Services Task Force. Screening for Preeclampsia: US Preventive Services Task Force Recommendation Statement. JAMA. 2017;317(16):1661-1667. Doi: 10.1001/jama.2017.3439

26 Task Force on Hypertension in Pregnancy. Hypertension in pregnancy. Washington (DC): American College of Obstetricians and Gynecologists; 2013

27 Henderson JT, Thompson JH, Burda BU, Cantor A. Preeclampsia screening: evidence report and systematic review for the US Preventive Services Task Force. JAMA. 2017;317(16):1668-1683. Doi: 10.1001/jama.2016.18315

28 American College of Obstetricians and Gynecologists' Committee on Practice Bulletins-Obstetrics. ACOG Practice Bulletin No. 203: chronic hypertension in pregnancy. Obstet Gynecol. 2019;133 (01):e26-e50. Doi: 10.1097/AOG.0000000000003020

29 World Medical Association. Declaration of Helsinki: ethical principles for medical research involving human subjects [Internet]. 2018 [cited 2020 Jan 23]. Available from: https://www.wma.net/polices-post/wma-declaration-of-helsinki-ethical-principles-for-medical-research-involving-human-subjects/

30 Uriel M, Romero XC. Reality of preeclampsia in Colombian pregnant women. Open Access J Gynecol.. 2016;1(01):000105
31 Abalos E, Cuesta C, Grosso AL, Chou D, Say L. Global and regional estimates of preeclampsia and eclampsia: a systematic review. Eur J Obstet Gynecol Reprod Biol. 2013;170(01):1-7. Doi: 10.1016/j.ejogrb.2013.05.005

32 Rana S, Lemoine E, Granger JP, Karumanchi SA. Preeclampsia: pathophysiology, challenges, and perspectives. Circ Res. 2019;124 (07):1094-1112. Doi: 10.1161/CIRCRESAHA.118.313276

33 Jamal A, Abbasalizadeh F, Vafaei H, Marsoosi V, Eslamian L. Multicenter screening for adverse pregnancy outcomes by uterine artery Doppler in the second and third trimester of pregnancy. Med Ultrason. 2013;15(02):95-100. Doi: 10.11152/ mu.2013.2066.152.aj1fa2

34 Arrue M, García M, Rodriguez-Bengoa MT, Landa JM, Urbieta L, Maitzegui M, et al. Do low-risk nulliparous women with abnormal uterine artery Doppler in the third trimester have poorer perinatal outcomes? A longitudinal prospective study on uterine artery Doppler in low-risk nulliparous women and correlation with pregnancy outcomes. J Matern Fetal Neonatal Med. 2017;30 (07):877-880. Doi: 10.1080/14767058.2016.1190822

35 Takahashi K, Ohkuchi A, Suzuki H, Usui R, Kuwata T, Shirasuna K, et al. Biophysical interaction between blood pressure and uterine artery Doppler for the occurrence of early-onset preeclampsia: A prospective cohort study. Pregnancy Hypertens. 2013;3(04): 270-277. Doi: 10.1016/j.preghy.2013.07.006 